\title{
The Porcupine and the End of History
}

Oklukirpi ve Tarihin Sonu

\author{
Baysar Taniyan \\ Pamukkale University, Turkey
}

\begin{abstract}
Set in a fictional East European country in the aftermath of the collapse of communism, Julian Barnes's The Porcupine (1992) is a political satire where he juxtaposes two dominant ideologies; capitalist liberal democracy and communism. Although this short novel has a conventional narrative form, postmodern discussions on history can be observed, especially the discussion which has revolved around the idea of "the end of history". It was Francis Fukuyama's controversial article entitled "The End of History" (1989) that has sparked this specific debate. In 1992, he elaborated his thesis in a book titled The End of History and the Last Man, the same year Barnes published his novel. Fukuyama suggests that the modern Western liberal democracy is the ultimate and the most successful form of human government, the point where the Hegelian dialectic of history comes to an end. The aim of this article is to present a critical reading of the novel in the context of Fukuyama's thesis and the discussion generated by this thesis. While it is true that Fukuyama's thesis has now been outdated and negated, this reading may still provide fresh insights for the current political panorama of the world shaped by surging nationalism, increasing populism and growing conservatism.
\end{abstract}

Keywords: Julian Barnes, The Porcupine, history, Francis Fukuyama, end of history

Öz

Komünizmin çöküşü sonrası kurgusal bir doğu Avrupa ülkesinde geçen Julian Barnes'ın Oklukirpi (1992) adlı romanı, kapitalist liberalizm ve komünizm gibi iki başat ideolojiyi karşı karşıya getiren politik bir hicivdir. Geleneksel bir anlatı biçimine sahip olmasına rağmen bu kısa romanda tarih üzerine, özellikle de "tarihin sonu" düşüncesine odaklanan postmodern tartışmaları takip etmek mümkündür. Bu özgül tartışma Francis Fukuyama'nın "The End of History?" (1989) başlıklı tartışmalı makalesi ile başlamıştı. Barnes'ın da romanının yayınlandığı 1992 yılında Fukuyama bu tezini, Tarihin Sonu ve Son İnsan adlı kitabında detaylandırmıștır. Fukuyama, modern liberal Batı demokrasisinin nihai ve en başarılı yönetim şekli olduğunu, yani Hegelci diyalektik tarihin sonu olduğunu önerir. Bu makalenin amacı, Barnes'ın romanının Fukuyama'nın tezi ve bu tezin ürettiği tartışmalar bağlamında eleştirel bir okumasını yapmaktır. Fukuyama'nın tezinin güncelliğini yitirdiği doğru olsa da bu okuma, yükselen milliyetçilik, artan popülizm ve büyüyen muhafazakârlık ile şekillenen dünyanın güncel siyasi görünümü hakkında yeni fikirler verebilir.

Anahtar Kelimeler: Julian Barnes, Oklukirpi, tarih, Francis Fukuyama, tarihin sonu

CUJHSS, December 2020; 14/2: 240-251. DOI: 10.47777/cankujhss.848919

(C) Çankaya University ISSN 1309-6761 Printed in Ankara

Submitted: Apr 30, 2020; Accepted: Sep 6, 2020

ORCID\#: 0000-0002-2843-8835; btaniyan@pau.edu.tr 
1989 was one of the milestones in human history as the world witnessed the collapse of Socialist regimes epitomised by the "Fall of Berlin Wall". In the same year, Fukuyama published his article entitled "The End of History?" and within this optimistic scene, he declared "an unabashed victory of economic and political liberalism" against all of its ideological competitors including "absolutism, then bolshevism and fascism, and finally an updated Marxism" (3). He starts his article by heralding that "something very fundamental has happened in world history" and then explains that fundamental thing as "the end point of mankind's ideological evolution and the universalization of Western liberal democracy as the final form of human government" ("The End of History?" 4). In other words, what Fukuyama suggests is the end of history "understood as a single, coherent, evolutionary process" (last man xii). By history, Fukuyama does not refer to crude events, wars, conflicts, but the progressive understanding of dialectical history formulated by the philosophy of history.

In his bold assumptions, Fukuyama is indebted to Hegel and his idea of evolutionary history. In his Lectures on the Philosophy of History (1837), Hegel strongly asserts that "reason governs the world, and that therefore world history is a rational process" (87), which is also "the progress of the consciousness of Freedom" (88). The reason dictates that man is destined to live in a society in which he would relish complete freedom:

Spirit's consciousness of its freedom (and along with it for the first time the actuality of its freedom) has been declared to be the reason of spirit in its determinacy. The latter is the destiny of the spiritual world, and (since the substantial, physical world is subordinated to the spiritual, or in the speculative sense has no truth over against it) it is the final end of the world in general. (Hegel 89)

Under the guidance of reason, human societies will eventually evolve into a form where "all" enjoy freedom, at which point the history will necessarily come to an end. Fukuyama regards Western liberal democracy as the point projected by Hegel and, therefore, he claims that history in this sense has come to an end. While Fukuyama's article could muster up support (Bloom et al. 1989), the text is obviously open to criticism as it is Eurocentric, a criticism which is also levelled at Hegel (Buchwalter 2009). For instance, Jacques Derrida directs a negative and severe criticism in Specters of Marx (1993):

For it must be cried out, at a time when some have the audacity to neoevangelize in the name of the ideal of a liberal democracy that has finally realized itself as the ideal of human history: never have violence, inequality, exclusion, famine, and thus economic oppression affected as many human beings in the history of the earth and of humanity. Instead of singing the advent of the ideal of liberal democracy and of the capitalist market in the euphoria of the end of history, instead of celebrating the 'end of ideologies' and the end of the great emancipatory discourses, let us never neglect this obvious macroscopic fact, made up of innumerable singular sites of suffering: no degree of 
progress allows one to ignore that never before, in absolute figures, have so many men, women and children been subjugated, starved or exterminated on the earth. (85)

In 1992, Fukuyama published a book titled The End of History and the Last Man, in which he reiterates his strong belief in the inevitable triumph of liberal democracy by referring to "the revelation of enormous weaknesses of ... seemingly strong dictatorships" and the spread of "the free market" (xiii) and by insisting that "the ideal of liberal democracy could not be improved on" (xi). While in the article, he identifies "religion and nationalism" ("The End of History?"14) as new challenges to liberal ideology, in the book, he posits identity politics, relatedly politics of recognition, as the weakness of the system (last man xiii-xxiii). In order to advance his argument, Fukuyama resorts to Plato and then, again, to Hegel. In the Republic, Plato divides the human soul into three parts: desire, reason, and thymos. Much of human action is organized by the first two. Thymos, which Fukuyama interprets as "selfesteem," is related to a person's sense of worth, or recognition by others (last man xvii). Emotions of anger, pride, and shame can be aroused depending on whether thymos is satisfied or not, and Fukuyama points out that Hegel holds these emotions responsible for historical change (last man xvii). For Fukuyama, reason and desire can explain the industrial revolution and transformations in economic life, but thymos is the ultimate fuel for liberal democracy as it provokes "a rational desire to be recognized as equal" (last man $\mathrm{xx}$ ). This democratic society requires taming of thymos and curbing all dangerous feelings of superiority. Consequently, Fukuyama suggests that "the typical citizen of a liberal democracy was a 'last man"' or '"men without chests,' composed of desire and reason but lacking thymos, clever at finding new ways to satisfy a host of petty wants through the calculation of long-term selfinterest" (last man xxii). The emerging problem here is that without thymos, man lacks aspiration or inspiration to create or to move forward and hence, he is no longer human. It is also, therefore, the point where history ends.

Fukuyama also acknowledges that "thymos is the fundamental source of human evil" (last man 181). In the world, thymos will always exist, and there will always be disagreements, arguments, or competitions for domination. Fukuyama, then, introduces new categories for thymos: megalothymia as the desire to be recognized as superior and isothymia, the desire to be recognized as the equal of other people (last man 182). He is still optimistic that liberal democracy will always provide new channels for the megalothymia to discharge its energy. What is interesting is that, in 1992, Fukuyama cited Donald Trump as a megalothymic personality whose personal ambitions are safely channelled into business far from political life (last man 328). No matter how one defines it, as historical necessity or as a twist of fate, or as contingency, to the disappointment of Fukuyama, Trump has ventured forth into politics and became the president of the United States. Moreover, while Brexit in the UK and extreme nationalist and populist governments at work in different liberal countries of Europe undermine the basic foundations and 
premises of liberal societies, contingent events, like the Covid-19 pandemic ${ }^{1}$, reveal how economically and socially vulnerable these societies are.

Upon such developments, in 2018, Fukuyama published another book, Identity: The Demand for Dignity and the Politics of Resentment. The first sentence of his Preface is, "this book would not have been written had Donald Trump not been elected president in November 2016" (ix). He admits that he did not "suspect back then that Trump would not be satisfied with business success and celebrity, but would go into politics and get elected president" (Identity xiv). He also comes to the understanding of "the difficulty of developing a modern, impersonal state" and "the possibility of a modern liberal democracy decaying or going backward" (Identity xii). With retrospect, he points out the failure of contemporary liberal societies in solving the problem of thymos and still claims that "it is not at all inconsistent with the general argument [he] was making about potential future threats to liberal democracy" (Identity xiv).

In the same year Fukuyama published The End of History and the Last Man, Julian Barnes published The Porcupine (1992). Interestingly, in an interview, Barnes explains that "it is a political novel about that old but still true problem: the weakness of liberalism confronted by the certainty of a system that it believes it has all the answers. And this is still the case even when liberalism has triumphed" (Conversations 46). In order to take this confrontation to its utmost limit, Barnes takes an overthrown communist dictator of a fictional East European country to the court. The country resembles Bulgaria in its passage from communism to liberalism in the early 1990s, and he corresponds with Dimitrina Kondeva, the Bulgarian translator of the novel, to collect information that would serve as raw material for his fiction (Kondeva 81-91). The idea for the novel emerges in Barnes's mind "in the middle of the night" with a very simple question: "What if a communist leader came to trial - what if, instead of running away or pretending he had cancer or whatever, what if he decided to defend himself by attacking?" (Conversations 25). He concedes that his experience of the Cold War cannot be compared to those living in Eastern Europe. However, the question still bothers Barnes as a "normal, sentient being" and "a child of the Cold War" whose adulthood had been shaped by that war (Conversations 25).

The trial is set at a time when that fictional country suffers from growing tension amidst the fears of slipping into total obscurity as the new order tries to navigate the country from communism to liberalism. In this context, the trial becomes highly symbolic because it provides the new order with a golden opportunity both to reckon with the old regime and legitimize and consolidate its newly acquired power.

Eventually, the former President sat down on the small hard chair that had been chosen for him. Behind, and therefore always in shot when

\footnotetext{
${ }^{1}$ Coronavirus disease (Covid-19) is a pandemic which started in December, 2019 in China. The disease quickly spread to the rest of the world bringing life to a halt. Governments all over the world met with severe criticism in their handling of the disease as their policies were blamed to prioritize financial matters over human life.
} 
Petkanov was on camera, stood an ordinary prison officer. The prosecution had arranged this little touch of stage management, and suggested in particular that a woman guard be chosen. The military were to be kept out of the picture as far as possible. See, this is just another civilian case in which a criminal is brought to justice; and look, he is no longer the monster who terrified us, he is just an old man guarded by women. (31)

The old man to be guarded by women is Stoyo Petkanov. Many critics believe that Barnes develops this character on Bulgarian communist ex-ruler Todor Zhivkov (Conversations 78). Although Barnes rejects this, he nevertheless points out that "[Petkanov] often speaks [Zhivkov's] lines" (Kondeva 87). However, only three charges could be brought against Petkanov: "The first, deception involving documents, related to the receipt of undue royalties ... The second, abuse of authority committed in an official capacity... The third, mismanagement, concerned a payment of undue social benefit" (39). The Special Office assigns Peter Solinsky as the prosecutor to confront Petkanov. Solinsky is well aware that mere conviction of the accused with such trivial charges like embezzlement and corruption would not be enough "for such a historic indictment" because condemning Petkanov necessarily means condemning the old order (39). The rule of the dictator should be devalued, and that can only be possible by changing how the nation perceives that regime. In other words, how the nation makes sense of its history.

Postmodern theories posit history as "a discursive construct" (Hutcheon 142). These theories emphasize that history and historiography are sites of conflict in which multiple discourses compete for power and claim to knowledge. Ideologically framed discussions in the court over the way Petkanov had ruled the country reveal the tension between the two adversary discourses in their pursuit to legitimize their versions. In "The Discourse of History," Roland Barthes indicates that the historical discourse "is in its essence a form of ideological elaboration" (16). Ideology also constitutes an important aspect in Hayden White's schematization of historiography, which conceptualizes ideology as a process

by which different kinds of meaning are produced and reproduced by the establishment of a mental set towards the world in which certain sign systems are privileged as necessary, even natural, ways of recognizing a 'meaning' in things and others are suppressed, ignored, or hidden in the very process of representing a world to consciousness. (192)

In constructing historical discourses and realities, selection under the guidance of a certain ideology is highlighted. It is, therefore, as Hutcheon states, "the meaning and shape are not in the events, but in the systems which make those past 'events' into present historical 'facts"' (89). As Buran claims "[h]istory is rewritten through remembering and telling the past" (379). By "incorporating the past into the present," postmodern historiography "advocates for a multiplicity of reality rejecting the standards on the past" (Buran 388). In 
Barnes's fictional country, there are "past events" that are publicly negotiated in the court and attested new meanings to transform them into historical facts and to give shape to new knowledge. In The Archaeology of Knowledge, Foucault asserts that "historical descriptions are necessarily ordered by the present state of knowledge, they increase with every transformation and never cease, in turn, to break with themselves" (5). In this sense, while the liberalist new order tries to remake the history of the country, the socialist old regime resists with adherence to old historical descriptions.

Defining himself as "the helmsman" of the nation, Petkanov boasts that "the Fascists have been routed" and "under [his] guidance, this country has grown in international stature" with reduced unemployment, controlled inflation and uninterrupted peace (121). He believes that the charges levelled against him are "convenient inventions" and pleads "guilty to the real charge," which is being "a Socialist and a Communist" (126). Against corruption allegations, Petkanov, then, revisits a past event concerning the prosecutor Solinsky's official visit to Italy as a trade delegate, for which the state provided him with "hard currency". He accuses Solinsky of spending that money "on a nice Italian suit," "on whisky," and "on taking a local woman to an expensive restaurant" with whom he spends the night together in a hotel room (86). Of course, this is, in the person of Solinsky, an attack against money-driven individualist capitalist ideology. While the old and experienced Petkanov successfully manipulates the course of the trial by undermining the credibility of Solinsky, Ganin, who works for The Special Office, is worried about the outcome of the trial:

It is important to hold this trial, for the good of the nation. It is equally important that the accused be found guilty. ... the nation expects from this trial something more than a technical verdict of guilty on a charge of minor embezzlement. Which is the direction in which you [Solinsky] are heading at the moment, with due respect. The nation expects to be shown that the defendant is the worst criminal in our entire history. (93-94)

The new order wants to change a historical category, or a historical description, existing in people's mind. To eradicate that image of Petkanov as the helmsman of the nation further efforts are required. Then, the prosecutor produces another historical document: a memorandum, "Just a half-page typed statement with two signatures attached. Not even signatures, initials" (91). The document "concerned the joint problems of internal dissent and external slander" and defines "Slander of the State" as "a form of sabotage" (91). It also reports that "the saboteurs" would be "discouraged by all necessary means" (91). Solinsky faces ethical dilemmas concerning the authenticity and accuracy of the document: “The document is true, even if it is a forgery. Even if it isn't true, it is necessary. Each excuse was weaker, yet also more brutal" (113). Overwhelmed by the great tension caused by this great historical responsibility, Solinsky feels desperate to resort to this dubious document. Referring to the document, he alleges that Petkanov has been involved in the 
sudden and mysterious death of his own daughter, a moment which also serves as the climax in the novel:

Peter Solinsky sat down to loudly unjudicial applause, to the drumming of feet, the thumping of desks, and even some raucous whistling. This was his moment, his moment for ever. He had thrust the pitchfork into the earth, one tine on either side of the neck. Look at him snarl and wriggle, spit and fret, pinned out there for all to see, exposed, witnessed, judged. This was his moment, his moment for ever. (111)

Even though the court declines this allegation, Solinsky considers himself and "his coup de theatre" successful in shifting "public perception decisively" (127). Despite the professional accomplishment, the judicial process destroys Solinsky's integrity, his wife deserts him and his daughter refuses to speak to him. On the other hand, Petkanov is sentenced to "thirty years of internal exile" and all his property is confiscated by the state. Petkanov loses everything; nevertheless, he feels himself to be "less defeated than this [Solinsky] ageing young man" (134-135).

As noted earlier, Barnes models his fictional country on Bulgaria. In 1990, he visited the country when Flaubert's Parrot was published in Bulgarian (Kondeva 82). Later he presented his observations on the country in an essay titled "Candles for the Living" in which he reports regular electricity cuts, exgymnasts' cabaret dance, rising interest in pornography, inflation, food coupons and rations, shortage of any kind, flourishing of the black market, and young people's migration even to South Africa. Particularly, his witty remarks on ex-gymnast dancers are noteworthy:

Sport is no longer state-coddled in Eastern Europe, so here are four gymnasts, deprived of coaching and steroids, earning their corn as a Sunday night cabaret act - a living demonstration of the switch from communism to capitalism. What sort of progress is this? Hard to tell; but it looks a neat image for the strange and extreme transformation Bulgaria is currently undergoing. ("Candles")

The essay is not only a display of pessimism, and Barnes expresses that the people could hold onto life with "a sense of irony". However, he locates the problem in the country's being geographically, historically, and genetically distant and distinct from the rest of Europe; "the forgotten item in the East European unshackling" ("Candles"). Due to its relative insignificance in world history, the country has been neglected, and the population, accordingly, could not glorify what they have undergone as a revolution but hesitantly devalue it as "the Changes". For all that, what most surprises Barnes in his trip is the phrase he hears: "the death of idealism," which indicates that the nation appears to have lost all their beliefs in "second chances" and, correspondingly, in the validity of discussing "how things should be, how they might be" ("Candles"). Defending socialism, Petkanov, in the novel, asserts that "[ $t]$ hings might not have been perfect, but with Socialism people could dream that one day they might be" (69). The atmosphere stirs a sense of weariness and caution 
regarding the present, and a sense of obscurity and uncertainty regarding the future, which is well reflected in the novel:

There had been a Revolution, of that there was no doubt; but the word was never used. ... This country had the fullest sense of history, but also a great wariness of rhetoric. The high expectations of the last years refused to declare themselves in tall words. So instead of Revolution, people here spoke only of the Changes, and history was now divided into three quiet parts: before the Changes, during the Changes, after the Changes. Look what had happened throughout history: Reformation, Counter-Reformation, Revolution, Counter-Revolution, Fascism, AntiFascism, Communism, Anti-Communism. Great movements, as by some law of physics, seemed to provoke an equal and opposite force. So people talked cautiously of the Changes, and this slight evasion made them feel a little safer: it was difficult to imagine something called the Counter-Changes or the Anti-Changes, and therefore such a reality might be avoidable too. (42)

The prosecutor Solinsky believes that passage to the new order, fashioned with the principles of liberal democracy, will be the ultimate solution that will save the nation. In this sense, in the public view, Solinsky "represented the new order against the old, the future against the past, virtue against vice" (37). When he delivered speeches in the media, "he customarily invoked the national conscience, moral duty, his plan of easing truth like a dandelion leaf from between the teeth of lies" (37). Petkanov, on the other hand, condemns the new order accusing it of "instability and hopelessness" and exalts Socialism as giving people what they want; "stability and hope" (69). For Petkanov, what Solinsky refers to as "swift achievements" can be listed as "[a] crime wave. The black market. Pornography. Prostitution. Foolish women gibbering in front of priests again" (69). Unlike Fukuyama, Petkanov believes that this is not the ultimate victory of Capitalism over Socialism. While Solinsky "and [his] sort have had many jumps" (106), this was the first jump of Socialism and one does not "get to Heaven at the first jump" (105). This is not the end of history and Petkanov is adamant that Socialism will eventually replace Capitalism:

What was happening was that just for a brief historical moment the old system was being allowed a last little hop in its slimy frog-pond. But then, inevitably, the spirit of Socialism will shake itself again, and in our next jump we shall squelch the capitalists down into the mud until they expire beneath our boots. (114-115)

Both Petkanov and Solinsky are in fact megalothymic characters defined by an obvious sense of superiority over others. For instance, Petkanov openly boasts that, as the "helmsman of [the] nation for thirty-three years" (60), he has "never asked much for [himself]" (83) and even donated "the Thracian gold" discovered on his land to a state museum (84). While he declares his life to be a sacrifice for improving the lives of workers and peasants, he asserts that he is "charged with bringing peace and prosperity and international respect to this country" (121). Fukuyama claims that "Communism humiliated ordinary 
people by forcing them to make a myriad of petty, and sometimes not so petty, moral compromises with their better natures" (Last Man 168). Likewise, Solinsky points out that "Party was always greater than the individual" (26). By accepting the appointment, he believes that he "was embarking on his most public form of self-definition" (37). However, according to his wife, "he was indulging his vanity again" and even for one of his colleagues, he had "a secret wish for television stardom" (36). His fame spreads all over the country but at the expense of his family, his credibility, and respect.

Barnes extends the end of history discussion with a subplot in which four university students, Vera, Stefan, Dimiter and Atanas, and Stefan's grandmother feature, a characterization which is highly symbolic as while the university students represent the younger generation and future, the grandmother becomes the representative of the older generation and the past. The subplot adds an essential dimension to the novel by taking the overtly theoretical discussion from the court to the real, practical life, which offers Barnes a chance to reflect how the real individual perceives these changes. A similar tension that of between Solinsky and Petkanov is then built up between these people.

As already pointed out, the new order regards the trial as an important opportunity to legitimize its power and, therefore, the whole legal process is publicized. To this end, the trial is televised, and the four university students watch the broadcast from their televisions despite regular electricity cuts. They are also highly conscious of the importance of the trial as they hold that they "were brought up ... to think that Socialism was the answer to everything, ... that Socialism was right, was scientific, that all the old systems had been tried and didn't work" (70). They will be "witnesses" (19) to "the nation's sudden passage from enforced adolescence to delayed maturity" (22), to this "great moment in their country's history" (19), in which they would bid "a farewell to grim childhood and grey, fretful adolescence" (20). The trial, for them, symbolizes "the end of lies and illusions," and finally, "the truth" would be possible (20). Stefan's grandmother, on the other hand, ignores the trial placing herself in the kitchen "underneath a small framed colour print of V.I. Lenin" and remaining silent almost throughout the novel (53). Compared to the enthusiasm of Stefan and his friends, her mood can be defined as wearied, even worried. For her, they are chatterers who gabble away and squabble "like a nestful of thrushes. Brains of thrushes, too" (54). Peter Childs also points out that "their youthful idealism, which sees only a change in history, is contrasted with the older people's awareness of cycles and patterns" (104). While on the surface, the grandmother seems to be pessimist regarding the current situation and the four university students appear to be hopeful, the grandmother clings to a glimmer of hope because she is still of the opinion that this is not the point in which the history ends:

How long would it be before the Party was banned again, forced to go underground? Before the Fascists resurfaced, and young men searched their attics for the faded green shirts of their Iron Guard grandfathers? 
Ahead she saw an inevitable return to the oppression of the working class, to unemployment and inflation being used as political weapons. But she also saw, beyond that, the moment when men and women would rise and shake themselves, recovering their rightful dignity and starting again the whole glorious cycle of revolution. She would be dead by then, of course, but she did not doubt that it would come to pass. (54-55)

Then what happens at the end of the novel and at the end of history? The novel has a powerful ending, though it does not let the reader enjoy an exact closure. As stated earlier, for Fukuyama, religion and nationalism still lurk somewhere as a threat to liberal democracy ("The End of History?" 14). At the end of the novel, the reader witnesses Solinsky's visit to the church St. Sophia, where he lights candles, "crossing himself, from right to left, in the Orthodox fashion" (137). The reader is also informed that "since the Changes, people had started coming back to the Church; not just for baptism and burial, but for worship, for unspecific consolation, for the knowledge that they were more than bees in a hive" (137). Fukuyama admits that "the end of history will be a very sad time" ("The End of History?" 18). Without thymos, there will be no place for courage, imagination or idealism and, hence, for artistic creativity and philosophic discussions, as they "will be replaced by economic calculation, the endless solving of technical problems, environmental concerns, and the satisfaction of sophisticated consumer demands" ("The End of History?" 18). Purified from his thymos, man becomes Nietzsche's "the last man" or "man without chest". Without any urge for creation, life becomes silent and boring, and this boredom, Fukuyama predicts, may restart history. Likewise, in the novel, the last three paragraphs strongly suggest "silence," as all three end with this word. The last paragraph, on the other hand, shows the grandmother holding a picture of Lenin. Although every passer-by abuses or teases her, she keeps her stand remaining silent, which may also signify the resilience of the old regime.

In front of the vacant Mausoleum of the First Leader an old woman stood alone. She wore a woollen scarf wrapped round a woollen hat, and both were soaked. In outstretched fists she held a small framed print of V.I. Lenin. Rain bubbled the image, but his indelible face pursued each passer-by. Occasionally, a committed drunk or some chattering thrush of a student would shout across at the old woman, at the thin light veering off the wet glass. But whatever the words, she stood her ground, and she remained silent. (138)

As a part of the conclusion, an attempt can be offered to locate the position the novel and the novelist take in the debate. The last three paragraphs of the novel may confuse the reader who intends to spot this position. For instance, Moseley argues that the old system is portrayed to be "more balanced than one might expect, or hope; it would be possible to read the novel as suggesting a nearly moral equivalence between Bolshevism and liberalism" (150). Yet, Barnes clarifies: 
If someone reads the Porcupine, reads the story of Petkanov, reads my account of his political thought and political operation, and then concludes that the book ends with 'a tribute' to communism, then they are simply a very dim reader. [...] I have come across this category of reader before, who looks at the ending of a novel and decides that it consists of the novelist's final beliefs in a disguised form. (qtd. in Guignery 63)

In the novel, as Socialism loses the monopoly of knowledge, Dimiter indicates that they have now realized that "there are two sides to every question" and complains that "just holding a trial is giving [Petkanov] false credit, is admitting that even in this case, even in this worst of cases, there is another side to the story" (71). In this context, Childs also suggests that the novel "remains sceptical of idealism and refuses either to see events from one side or to take comfort from political or religious rhetoric" (99). Concomitantly, Barnes's voice is "uncommitted, slightly detached, and therefore seemingly wellbalanced," which "detects disturbing traces of sound reason and logic in the justifications offered by Petkanov and sees Solinsky as someone with power and history, rather than morality, on his side" (99). Childs concludes that "Barnes is in no wise a simple reactionary but is predisposed to see the arguments on both sides, and put them to the reader" (99-100). On the other hand, Alberto Lázaro perceives the novel as "a committed political satire" (123), which "works through subtlety and suggestion" (127). Lázaro argues that the main conflict in the novel is not between Communist and Capitalist ideologies but "between the unacceptable corruption that often entraps politicians and the implicit honesty that should reign over the political sphere" (123). In other words, peculiar to satire tradition, the battle between good and evil is perceivable, and while the values like prudence, fairness and righteousness that the writer advocates are hidden, the evil is highlighted (Lázaro 123-124). Lázaro explains Barnes's authorial absence as "detachment," another satire technique which requires authorial disengagement from the story. "The narrators of satiric fiction are just speaking voices who do not explicitly condemn what they try to expose nor feel sympathy for their characters" (Lázaro 128). Barnes is able to mute his voice in his third-person omniscient narration by using "indirect interior monologue" in which through "self-revelation," characters exhibit their "vicious nature," which is "more dramatic and convincing way" of criticism (Lázaro 129). Therefore, the reader never feels the authorial presence of Barnes and is alone to decide whether this is the end of history or not.

What Barnes seems to emphasize in fact, is the rhetoric, no matter where it comes from exasperates the people. As the novel also strongly suggests, theoretical discussions held in upper parts of society seldom have a significant effect on the practical life of the lower parts. Names given to squares might be changed, or statues of heroes might be removed from the heart of the cities to wastelands, or once-traitors might be announced martyrs. In the novel, it is quite significant that when asked his idea about the removal of one of the 
statues, the taxi driver speaks clearly that he does not "give a fuck either way" (128). That is also why Barnes makes a group of protestors ironically cry in capital letters, "GIVE US IDEOLOGY NOT BREAD" (46). That also explains why Atanas, with a hint of irony and half-mockingly, expresses that as they are free now, he wants to use his "freedom not to be serious" and "to be frivolous for the rest of [his] life" (133). This is the sense of irony, as Barnes observes in "Candles for the Living," by which the nation tries to cope with the harsh realities of life and one of the fundamental realities of life is that dominant ideologies may replace one another, but human nature remains the same, and there will always be megolathymic characters, like Trump, Petkanov or Solinsky.

\section{Works Cited}

Barnes, Julian. "Candles for the Living". London Review of Books, 6 Nov. 2019, www.lrb.co.uk/the-paper/v12/n22/julian-barnes/candles-for-the-living.

--. Conversations with Julian Barnes, edited by Vanessa Guignery and Ryan Roberts. University Press of Mississippi, 2009.

---. The Porcupine. Alfred A. Knopf, 1992.

Barthes, Roland. "The Discourse of History," Comparative Criticism, vol. 3, 1981, 7-20.

Bloom, Allan, et al. "Responses to Fukuyama," The National Interest, no. 16, 1989, pp. 19-35.

Buchwalter, Andrew. "Is Hegel's Philosophy of History Eurocentric?" Proceedings of the Hegel Society of America, 19, Hegel and History, 2009, pp. 87-110.

Buran Utku, Sumeyra. "hiSTORiographic Metafiction of the Past Time: A self-begetting novel To Whom It May Concern," Kafkas University Journal of the Institute of Social Sciences, vol. 22, Autumn 2018, pp. 377-389.

Childs, Peter. Julian Barnes. Manchester University Press, 2011.

Derrida, Jacques. Specters of Marx. Trans. Peggy Kamuf, Routledge, 1994.

Foucault, Michel. The Archaeology of Knowledge. Routledge, 2002.

Fukuyama, Francis. “The End of History?” The National Interest, no. 16, 1989, pp. 3-18.

---. The End of History and The Last Man. Penguin Books, 1992.

---. Identity: The Demand for Dignity and the Politics of Resentment. Farrar Straus and Giroux, 2018.

Guignery, Vanessa. "Untangling the Intertwined Threads of Fiction and Reality in The Porcupine (1992) by Julian Barnes." Pre and Post-publication Itineraries of the Contemporary Novel in English, edited by Vanessa Guignery, Publibook, 2007. pp. 49-71.

Hegel, Georg W. F. Lectures on the Philosophy of World History, vol. 1, Manuscripts of the Introduction and The Lectures of 1822-3, edited by Robert F. Brown and Peter C. Hodgson, Clarendon Press, 2011.

Hutcheon, Linda. A Poetics of Postmodernism. Routledge, 1995.

Kondeva, Dimitrina. "The Story of Julian Barnes's The Porcupine: An Epistolary 1/2 Chapter." Julian Barnes: Contemporary Critical Perspectives, edited by Sebastian Groes and Peter Childs, Continuum Press, 2011, pp. 81-92.

Lázaro, Alberto. “The Techniques of Committed Fiction: In Defence of Julian Barnes's The Porcupine," Atlantis, vol. 22, no. 1, 2000, pp. 121-131.

Moseley, Merritt. Understanding Julian Barnes. University of South Carolina, 1997.

White, Hayden. The Content of the Form: Narrative Discourse and Historical Representation. The John Hopkins University Press, 1990. 